\title{
Debts and discharges
}

I wish to record my thanks to the librarians of the Perry Library of South Bank University, the British Library of Political and Economic Sciences; the libraries of the School of Oriental and African Studies and the Szkoła Główna Handlowa; and the British Library, and Tish Collins of the Marx Memorial Library, for their assistance in my research for this book. The generosity of the Amiel-Melburn Trust, the Leverhulme Foundation, and the European Commission's research network on Financial Integration and Social Cohesion has helped to defray expenses associated with broader research, of which this is one outcome. Especial thanks are due to Anita Prażmowska for her unique encouragement of my efforts to overcome the obstacles that academic employment today throws in the path of intellectual endeavour. That employment, however, also brought into the orbit of my discussions some talented and enthusiastic students on whom I was able to try out many of the ideas in this book. When those ideas became serious I was able to discuss them more knowledgeably with David Gowland, Leslie Fishman, Peter Howells, Jesper Jesperson, Julio Lopez-Gallardo, Tracy Mott, Geert Reuten, Zvi Schloss, Nina Shapiro, Geoff Tily, Tadeusz Kowalik and Randy Wray. I am grateful to Mary French-Sokol for advice on Jeremy Bentham and his writings; to Ian King and Claudia Jefferies for their assistance in translating Marek Breit's 1935 article from German; and to David Cobham, Gary Dymski, Susan Howson, John King, Andy Denis, Alfredo Saad-Filho, Warren Samuels and Geoff Harcourt for comments on an earlier draft and various chapters in the book. Especial thanks are due to Victoria Chick, who has been the most consistent and sympathetic critic of my work. She and Geoff Harcourt generously gave time and trouble to look at my drafts in the frantic crisis-ridden months as this book was being completed. None of the individuals listed here saw the book as a whole and, therefore, they bear no responsibility for its overall content and conclusions.

At a crucial stage in the emergence of the book, in September 2001, I was invited to give a series of lectures at the Faculty of Economics of the Universidad Nacional Autónoma de México. The opportunity to discuss the ideas in this book with Noemi Levy-Orlik, Alicia Giron, Guadalupe Mantey, Eugenia Correa and their students made an invaluable contribution towards clarifying my arguments. Later on, aspects of the book were discussed at a presentation for Economics staff at the Open University. At around this time, 
a draft containing the results of my investigations in classical political economy floated off to appear in the annual History of Economic Thought and Methodology, Volume 22-A, as 'The Prudence of Projectors'. Completion of the book was made possible by the shelter generously provided by John Weeks, Machiko Nissanke and the Economics Department at London University's School of Oriental and African Studies. The book owes more than is apparent to the enthusiasm and interest of all these individuals. The author takes responsibility for the remaining errors. The enthusiast for new ideas, and novel approaches to old ideas, is especially prone to overlook mistakes in pursuit of some immanent conception that inspires research. I hope that the remaining blemishes are small enough to be overlooked in that greater construction, and that the kindness of many friends is reflected in its qualities.

The most personal debt is owed to Anita Prażmowska and Miriam Prażmowska-Toporowska. Their tolerance of literary dementia and support in difficult times deserves more gratitude than can be expressed here, and a monument more beautiful than anything a mere economist can create. 